\title{
Organizational Climate and Teachers Job Performance in Public Secondary Schools in Abia State, Nigeria
}

\author{
Ahitub Okpo Njoku, M. N. Modebelu* \\ Department of Educational Management, Michael Okpara University of Agriculture, Umudike, Nigeria \\ Email: *meloodyne@gmail.com
}

How to cite this paper: Njoku, A.O. and Modebelu, M.N. (2019) Organizational Climate and Teachers Job Performance in Public Secondary Schools in Abia State, Nigeria. Open Access Library Journal, 6: e5751.

https://doi.org/10.4236/oalib.1105751

Received: September 2, 2019

Accepted: October 26, 2019

Published: October 29, 2019

Copyright $\odot 2019$ by author(s) and Open Access Library Inc.

This work is licensed under the Creative Commons Attribution International License (CC BY 4.0).

http://creativecommons.org/licenses/by/4.0/

\section{(c) (i) Open Access}

\begin{abstract}
This study investigated the Organizational climate and teachers job performance in public secondary schools in Abia state, Nigeria. Two research questions and two null hypotheses guided the study. Ex-post facto descriptive survey design was employed in the study. Proportionate sampling technique was used to determine a sample size of 609 respondents for the study. A structured questionnaire titled "Organizational Climate on Teachers Job Performance Questionnaire (OCTJPQ)" built on 4-point rating scale was used for data collection. The face validity of the instrument was established by three experts, two from Educational Management and one from Measurement and Evaluation in Michael Okpara University of Agriculture, Umudike. Reliability of the instrument was determined with Cronbach alpha technique which gave a value of 0.84 for the internal consistency. Data collected analyzed with mean and standard deviation for the research questions while null hypotheses were tested with t-test statistic tool at 0.05 level of significance. Findings among others showed that open organization climate influences teachers' job performance to a low extent, and there was no significant difference between the mean scores responses Principals and teachers on the two null hypotheses. Based on the findings, recommendations were advanced.
\end{abstract}

\author{
Subject Areas \\ Education, Sociology \\ Keywords \\ Organizational Climate, Teachers, Job Performance, Public Secondary Schools
}

\section{Introduction}

The development of any nation is primarily dependent on the educational sys- 
tem available in the country. Education cannot function effectively without teachers playing vital roles in ensuring achievements of instructional objectives in educational institutions. Educational institution, such as secondary schools represent educational organization. An organization is an entity where there is an engagement of a group of people working together to achieve a common goal and objective Ige [1]. Educational organization is an entity where there is an engagement of students, teachers, and non-teaching staff Modebelu, and Duvie [2]. The quality of relationship in school organization is a factor of organizational (climate these play significant roles in the management and administration of the school organization as well as enhances teacher job performance and success. In secondary schools, positive school organizational climate is recognized as an important target for school reform, improved behavior of students and teachers good academic performance. Organizational climate, according to Thompson [3], is an approach in which organizational members observe and characterize their surroundings and environment in an attitudinal and value base manner. Ajayi and Mandakini [4] defined organizational climate as the formal system of tasks and reporting relationships that control, coordinate, and motivate employees that they cooperate to achieve an organizational goal. He further categorized school organizational climate that can influence teachers' job performance into six such as open, close, autonomous, controlled, paternal and familiar climates. The researcher decided to explore open and close organizational climate for these report. Open climate is characterized by cooperation, intimacy, mutual interaction and concern for one another, while close climate indicates uncooperative attitudes and lack of concern for peoples' needs and problems. Teachers job performance indicates the level, way, manner, process and commitment of teachers job performance in terms of performance of teaching, lesson preparation, presentation, actual instructional delivery and teachers commitment to their job, extracurricular activities, supervision, motivating and morale among others. It is against this background that this study sought to investigate the influence of organizational climate on teachers' job performance in public secondary schools in Abia State.

\subsection{Statement of the Problem}

In actual sense, secondary schools in the three education zones (Aba, Ohafia and Umuahia) in Abia State, Nigeria need to enjoy a serene and conducive organizational climate. In Abia State secondary school of today, the reverse seems to be the case. Thus, incessant conflicts among and between staff, administrators or students, non-involvement of majority of male and female teachers in decision or educational stakeholders, poor implementation of teachers' condition of service to the extent that teachers seemed to be owed for five months arears. That might be the cause of apparent poor teachers job performance in the public secondary schools. Principals and teachers quarrel and report cases tendered to the Secondary Education Management Board (SEMB). This could also be the source 
and cause of inadequate organizational climate in schools. This issue could be traced to many variables, hence the problem of the study put in question form reads: to what extent does organizational climate influence teachers job performance in public secondary schools in Abia State?

\subsection{Purpose of the Study}

The study examined the influence of organizational climate on the job performance of teachers in public secondary schools in Abia State Nigeria. The specific objectives sought to:

1) Determine the extent to which open organizational climate influences teachers' job performance in public secondary schools in Abia State.

2) Find out the extent closed organizational climate influences teachers job performance in public secondary schools in Abia State.

\subsection{Research Questions}

The following research questions were answered as guide to the study:

1) To what extent does open organizational climate influence teachers' job performance in public secondary schools in Abia State?

2) To what extent does closed organizational climate influence teachers job performance in public secondary schools in Abia State.

\subsection{Hypotheses}

Two null hypotheses were tested at 0.05 level of significance as a guide to the study:

$\mathrm{HO}_{1}$ : There is no significant difference between the mean score responses of principals and teachers on the extent open organizational climate influence teachers job performance in public secondary schools in Abia State.

$\mathrm{HO}_{2}$ : There is no significant difference between the mean score responses of principals and teachers on the extent closed organizational climate influences teachers job performance in public secondary schools in Abia State.

\subsection{Methodology}

The study adopted ex-post facto and descriptive survey designs. It study covered the all the public secondary schools in the 17 local government areas in the three education zones in Abia State, Nigeria. The population was 3970 subjects consisting of 235 principals and 3735 teachers in 235 public secondary schools. A sample size of 609 consisting 374 teachers and 235 principals were selected using proportionate stratified random sampling technique and by simple random sampling technique by balloting without replacement was employed for sampling the respondents for the study. A structured questionnaire titled "Organizational Climate on Teachers Job Performance Questionnaire (OCTJPQ)" was used for data collection. The face validity of the instrument was established by three experts, two from Educational Management and one from Measurement 
and Evaluation all from College of Education, Michael Okpara University of Agriculture, Umudike. The reliability coefficient was determined by administering 80 copies of questionnaire to 80 principals and teachers from the schools in Orlu Educational Zone in Imo State to ensure homogeneity. Data collected were analyzed using Cronbach alpha technique and0.84 internal consistency value was obtained. With the help of five trained Research Assistants the researchers administered 609 copied to 609 subjects. All were returned used for analyses. While the research questions were answered with mean and standard deviation, null hypotheses were tested with $\mathrm{t}$-test statistic tool at 0.05 level of significance.

\subsection{Results and Discussion}

The analyses and presentation of results were organized around the research questions and null hypotheses. The presentation of data was based on data generated from 609 respondents which comprised 384 teachers and 235 principals in Abia State secondary schools who filled and returned the instrument for data presentation.

\subsection{Research Question 1}

To what extent does open organizational climate influence teachers job performance in public secondary school In Abia State?

Results in Table 1 revealed mean responses of principals and teachers in Abia state onthe extent of influence of open organization climate on teachers' job performance. A pooled mean of 1.83 was far below the weighted mean of 2.50 indicating that all the 5 items on open organization climate influence to a low extentteachers' job performancein the study area. item by item analysis revealed items 1, 2, 3, 4 and 5 respectively scored below the weighted mean of 2.50 .

Table 1. Mean ratings of respondents on the extent open organizational climate influences teachers' job performance in public secondary schools in Abia State

\begin{tabular}{|c|c|c|c|c|c|c|c|}
\hline S/N & $\begin{array}{l}\text { Extent of influence of open organizational climate on } \\
\text { teachers' job performance in public secondary schools }\end{array}$ & $\mathbf{N}$ & $\begin{array}{l}\text { Teachers } \\
\bar{X}_{1}\end{array}$ & S.D & $\begin{array}{l}\text { Principal } \\
\bar{X}_{2}\end{array}$ & S.D & Decision \\
\hline 1. & $\begin{array}{l}\text { The open organization climate in the school influences } \\
\text { teachers' job performance. }\end{array}$ & 609 & 2.33 & 1.92 & 1.92 & 1.66 & Low extent \\
\hline 2. & $\begin{array}{l}\text { The open organizational climate of genuine concern for } \\
\text { duties in my school influences teachers' job performance. }\end{array}$ & 609 & 2.47 & 1.85 & 2.26 & 1.91 & Low extent \\
\hline 3. & $\begin{array}{l}\text { Being considerate with decision-making organizational } \\
\text { climate in my school influences teachers' job performance. }\end{array}$ & 609 & 2.09 & 2.44 & 2.45 & 2.13 & High extent \\
\hline 4. & $\begin{array}{l}\text { The open organizational climate for motivating teachers in } \\
\text { my school influences teachers job performance }\end{array}$ & 609 & 1.88 & 1.88 & 2.21 & 1.90 & Low extent \\
\hline 5. & $\begin{array}{l}\text { The open organizational climate that creates room for } \\
\text { principals and teachers to be supportive in my school } \\
\text { influences teachers job performance. }\end{array}$ & 609 & 1.68 & 1.61 & 2.26 & 1.91 & Low extent \\
\hline & Pooled Mean & 609 & 2.03 & 1.5 & 1.83 & 1.22 & Low extent \\
\hline
\end{tabular}


That was an indication that principals and teachers generally agree that these items on extent open organizational climate influence teachers job performance to a low extent in secondary schools in Abia State.

\section{Research Question 2}

To what extent do closed organizational climate influence teachers' job performance in public secondary schools in Abia State?

From Table 2, items 6, 7, 8, 9 and 10 respectively scoring below the weighted mean of 2.50 indicated that principals and teachers generally agree that these items on closed organizational climate influence teachers' job performance to a low extent in public secondary schools in Abia State.

$\mathrm{HO}_{1}$ : These is no significant difference between the mean score responses of principals and teachers on the extent open organizational climate influences teachers job performance in public secondary schools Abia State.

The means scores of the two groups were subjected to t-test statistic. The result presented in Table 3. Shows that there is no significant difference between the mean rating of the two groups. This is because the $t$-calculated (1.3409) is less than the $t$-tabulated of 1.96 with degree of freedom 607 . Since the value of $t$

Table 2. Mean ratings of respondents on the extent closed organizational climate influence teachers' job performance in public secondary schools in Abia State?

\begin{tabular}{|c|c|c|c|c|c|c|c|}
\hline$S / N$ & $\begin{array}{l}\text { Extent closed organizational climate influences teachers' } \\
\text { job performance in public secondary schools }\end{array}$ & $\mathbf{N}$ & $\begin{array}{l}\text { Teachers } \\
\bar{X}_{1}\end{array}$ & S.D & $\begin{array}{l}\text { Principal } \\
\bar{X}_{2}\end{array}$ & S.D & Decision \\
\hline 6 & $\begin{array}{l}\text { Closed organization climate which does not create room for } \\
\text { teachers and principals to cooperate effectively influences } \\
\text { teachers interest in teaching }\end{array}$ & 609 & 2.04 & 0.65 & 1.92 & 1.66 & Low extent \\
\hline 7 & $\begin{array}{l}\text { Closed organizational climate which does not allows principals } \\
\text { and teachers to cooperate effectively in my school influences } \\
\text { teachers job performance }\end{array}$ & 609 & 2.36 & 0.71 & 2.26 & 1.91 & Low extent \\
\hline 8 & $\begin{array}{l}\text { Closed organizational climate depicting principals and teachers } \\
\text { inability to show genuine concern to duties in my school } \\
\text { influences teachers job performance }\end{array}$ & 609 & 2.02 & 0.64 & 2.45 & 2.13 & Low extent \\
\hline 9 & $\begin{array}{l}\text { Closed school climate that restrict motivation of principals and } \\
\text { teachers in my school influence teachers job performance. }\end{array}$ & 609 & 2.42 & 0.71 & 2.21 & 1.90 & Low extent \\
\hline 10 & $\begin{array}{l}\text { The school closed organizational climate inability to create } \\
\text { room for principals and teachers to be supportive influences } \\
\text { teachers methods of assessing students' performance }\end{array}$ & 609 & 2.36 & 0.71 & 2.26 & 1.91 & Low extent \\
\hline & Pooled Mean & 609 & 2.24 & 1.5 & 2.22 & 1.22 & Low extent \\
\hline
\end{tabular}

Table 3. t-test analysis of principals and teachers responses on the extent open organizational climate influences teachers' job performance in public secondary schools in Abia State.

\begin{tabular}{cccccccc}
\hline Group & N & $\bar{X}$ & SD & Df & Level & & \\
\hline Teachers & 374 & 2.03 & 1.5 & 607 & 0.05 & -1.3409 & 1.96 \\
Principals & 235 & 1.83 & 1.22 & & & & \\
Total & 609 & & & & & & \\
\hline
\end{tabular}


observed is less than t-tabulated, we would accept null hypothesis. This implies that there is no significant difference between the mean score responses of principals and teachers on the extent open organizational climate influences teachers job performance in public secondary schools in Abia State.

\subsection{Hypothesis 2}

$\mathrm{HO}_{2}$ : There is no significant difference between the mean score responses of principals and teachers on the extent closed organizational climate influences teachers' job performance in public secondary schools in Abia State.

The mean scores of two groups were subjected to t-test statistic. The result presented in Table 4 shows that there is no significant difference between the mean ratings of the two groups. This is because the t-tabulated of 1.96 with degree of freedom 607 . Since the value $t$-observed is less than $t$-tabulated, we would accept the null hypothesis. This implies that there is no significant differences between the mean score responses of principals and teachers on the extent close organizational climate influences teachers job performance in public secondary schools in Abia State.

\subsection{Discussion of Findings}

The study was aimed at investigating extent organizational climate influence teachers' performance in secondary schools Abia State which was discussed under the following specific objectives:

1) The extent to which open organizational climate in influences teachers' job performance in public secondary schools in Abia State.

2) The extent closed organizational climate influences teachers' job performance in public secondary schools in Abia State.

The extent to which open organizational climate influences teachers job performance in public secondary schools in Abia State.

Results from Table 1, indicated that principals and teachers agreed that there were a low extent influence of open organizational climate on effective cooperation $(\bar{x}=2.22,1.97)$ show genuine concern to their duties and this influences teachers relationship with students $(\bar{x}=2.90,2.45)$, the school organization creates no room for motivation of teachers and principals and which influences teachers methods of teaching $(\bar{x}=1.88,2.21)$ and the school climate creates no room for principals and teachers to be supportive and which influences teachers

Table 4. t-test analysis of principals and teachers responses on the extent closed organizational climate influences teachers job performance in public secondary schools in Abia State.

\begin{tabular}{cccccccc}
\hline Group & N & $\bar{X}$ & SD & Df & Level & & \\
\hline Teachers & 374 & 2.24 & 1.5 & 607 & 0.05 & -1.4409 & 1.96 \\
Principals & 235 & 2.22 & 1.22 & & & & \\
Total & 609 & & & & & & \\
\hline
\end{tabular}


methods of assessing students' performance $(\bar{x}=1.68,2.26)$ from the pooled mean, the table shows that open climate to a low extent influence teachers job performance in secondary schools in Abia State $(\bar{x}=2.09,2.22)$. The findings of the study justifies Ajayi and Manadkini [4] as well as Salamat, Samsu and Kannalu [5] saying that open organizational climate is a significant factor that could effect teachers job performance. Teachers in Abia State are advised to practice open climate in their day to day activities.

The extent closed organizational climate influences teachers job performance in public secondary schools in Abia State.

From Table 2, items 6, 7, 8, 9 and 10 respectively indicate that teacher and principals to a low extent does not create room in organization to cooperate effectively and as a result influences teachers interest in teaching $(\bar{x}=2.04,1.92)$, inability of principals and teachers to show genuine concern to their duties influence teachers relationship with students $(\bar{x}=2.36,2.26)$, the inability of organization to create room for the principal to be considerate in decision-making influences teachers classroom management $(\bar{x}=2.02,2.45)$, the school organization do not create room for the motivation of teachers method of teaching $(\bar{x}$ $=2.42,2.21)$ and the school organization inability to create room for principals and teacher to be supportive influences teacher methods of assessing students' performance $(\bar{x}=2.36,2.26)$. from the pooled mean the table shows that closed organizational climate to a low extent influence teachers job performance in secondary schools in Abia State $(\bar{x}=2.22,2.24)$. premise on the findings, Onyene[5] supportive the findings of the study. He opined that closed organizational depicts lack of commitment and non productivity. Hoy and Sabo [6] revealed that principals in this situation is very rigid, inconsiderate unsupportive and unresponsive.

The primary purpose of this study is to examine the influence of organizational climate on teachers job performance in public secondary schools in Abia State to achieve the purpose of the study, two research questions and two null hypotheses were formulated to guide the study. Cronbach Alpha coefficient test was used to test the reliability. While t-test was used to analyze the null hypothesis at 0.05 level of significance, with t-tabulated of 1.96 and degree of freedom 607.

The results of the analyses revealed that open organizational climate and closed organizational climate to a low extent influences teachers job performance in public secondary school, Abia State.

\section{Conclusion}

Based on the discussion of findings of this study, the following conclusions are made that open organizational climate and closed organizational to a low extent influence teachers' job performance in public secondary schools in Abia State.

\section{Recommendations}

Based on the findings of this study, the researcher made the following recom- 
mendations:

1) Government and secondary school administrators should provide adequate organizational climate in our secondary schools.

2) Principals should encourage decision-making process in their staff meetings and give a freehand for every members' contribution.

3) Government should outline bad related behaviours of teachers and exibit prompt payment of salaries and allowances, promotions should be implemented without delay.

\section{Conflicts of Interest}

The authors declare no conflicts of interest regarding the publication of this paper.

\section{References}

[1] Ige, J.A. (2011) Teachers Data in Secondary Schools in Ekiti State. Permanent Secretary at the Senior Staff Seminar, Ministry of Education, Ado-Ekiti, 5-9.

[2] Modebelu, M.N. and Duvie, A.N. (2013) New Trends and New Challenges in Educational Leadership and Governance in Nigeria. African Journal of Agricultural Research and Development, 6, 69.

[3] Thompson, M.D. (2005) Organizational Climate and Culture Perception and Job Element Satisfaction: A Multi-Frame Application in a Higher Education Setting. E-Journal of Organizational Learning and Leadership, 4, 71-77.

[4] Ajayi, B. and Mandakini, K. (2013) Organizational Climate as a Predictor of Teacher Effectiveness. European Academic Research, 1, 553-568.

[5] Salamat, N., Sansu, N.Z. and Kamalu, S.M. (2013) The Impact of Organizational Climate on Teachers' Job Performance. Educational Research Journal, 2, 71-82. https://doi.org/10.5838/erej.2013.21.06

[6] Hoy, W.K. and Sabo, D.J. (2008) Quality Middle Schools: Open and Healthy. Corwin Press Inc., California. 